\title{
Comparative Efficacy of Nebulized 3\% Hypertonic Saline versus $0.9 \%$ Normal Saline in Children with Acute Bronchiolitis
}

\author{
KHANDAKER TAREQUL ISLAM ${ }^{1}$, ABID HOSSAN MOLLAH ${ }^{2}$, ABDUL MATIN $^{3}$, MAHMUDA BEGUM $^{4}$
}

\begin{abstract}
Background: Acute bronchiolitis is leading cause of hospitalization in infants below 2 years of age. Bronchiolitis being a viral disease, there is no effective treatment. 3\% nebulized hypertonic saline and 0.9\% nebulized normal saline are often used, although there is disagreement over their efficacy. The aim of this study was to evaluate the efficacy of $3 \%$ hypertonic saline in children with acute bronchiolitis in reducing clinical severity and length of hospital stay.

Methodology: A randomized control trial carried out in the Department of Pediatrics, Dhaka Medical College Hospital from January 2013 to December 2013. Ninty children from 1 month to 2 years of age hospitalized with clinical bronchiolitis were randomized to receive $3 \%$ nebulized hypertonic saline(Group-I) or $0.9 \%$ nebulized normal saline (Group-II). Nebulization was done 8 hourly until discharge. Outcome variable were clinical severity score, duration of oxygen therapy and length of hospital stay.

Results: Baseline clinical severity score and $\mathrm{O} 2$ saturation were in group-I $9.0 \pm 1.0$ and $94.9 \pm 1.7$ and in group- $/ / 9.3 \pm 1.8$ and $94.6 \pm 2.6$ respectively ( $p>0.05)$. At 72 hours, the mean severity score for the group-I was $1.64 \pm 0.99$ and that for the group-Il was $3.0 \pm 1.48(95 \% \mathrm{Cl}-2.17$ to $-0.53, p=0.002)$. The cases of group-I required a shorter duration of oxygen therapy compared to those of group-II (15.0 16.0 hours vs $26.4 \pm 5.37$ hours, $95 \% \mathrm{Cl}-20.35$ to $-2.44, p<0.05)$. Forty two (93.3\%) of the group-I children recovered by the end of72 hours and discharged whereas 26 (57.8\%) of the group-II children recovered during the same period $(p<0.05)$. Length of hospital stay was shorter in group-I compared to group-II (58.1 \pm 22.0 hours vs $74.7 \pm 27.2$ hours, $95 \% \mathrm{Cl}-26.89$ to- $6.17, p=0.002)$. None of the cases encountered any side-effects.
\end{abstract}

Conclusion: Nebulization with 3\% hypertonic saline significantly reduced clinical severity, length of hospital stay and duration of oxygen therapy in case of acute bronchiolitis in comparison to $0.9 \%$ normal saline and was safe.

Key words: Bronchiolitis, Nebulized 3\% hypertonic saline, 0.9\% normal saline.

\section{Introduction}

Bronchiolitis is an acute inflammatory lesion of the lower respiratory tract. More than $70 \%$ cases are caused by respiratory syncytial virus (RSV); other less common pathogens include parainfluenza, influenza, rhinovirus, adenovirus, human metapneumovirus, human bocavirus and mycoplasma pneumonae ${ }^{1,2}$. Children become infected with RSV by age 2 years

1. Junior Consultant, Department of Pediatrics, Shaheed Suhrawardy Medical College Hospital, Dhaka

2. Professor, Department of pediatrics, BIRDEM, Dhaka.

3. Professor, Department of pediatrics, Dhaka Medical College.

4. Junior Consultant, Upazilla Health Complex, Keranigonj, Dhaka Correspondence: Dr. Khandaker Tarequl Islam, Junior Consultant, Department of Pediatrics, Shaheed Suhrawardy Medical College Hosputal, Dhaka. E- mail-khandakeri40@yahoo.com

Received: 01 March 2018 with peak incidence being in 2-6 months ${ }^{3-5}$. Only $1 \%$ of these children require hospitalization6. In a recent study in different hospitals of Dhaka city, 348 cases were diagnosed as bronchiolitis and were found positive for RSV antibody in $50 \%$ these cases ${ }^{7}$.

Bronchiolitis is an infection of the bronchiolar epithelium, characterized by necrosis and sloughing of epithelial cells, oedema, increased secretion of mucus, and peribronchiolar mononuclear infiltration - changes that obstruct flow in the large and small airways, leading to hyperinflation, atelectasis and wheezing 6,8 .

Despite 4 decades of efforts to deal with the problem, there is no evidence-based clinically effective treatment of bronchiolitis ${ }^{6}$. The standard treatment 
for acute bronchiolitis remains supportive care like ensuring sufficient oxygenation and maintaining adequate hydration and nutrition ${ }^{8}$. Bronchodilators like salbutamol, adrenaline, anti-cholinergic drugsipratropium bromide and saline nebulization have been used with varying results. There is lack of sufficient evidence for almost all the interventions that are usually tried, including inhaled epinephrine, bronchodilators, steroids, anticholinergics, antibiotics, surfactant and chest physiotherapy. None of the treatment modalities is specific. Antiviral agents are available, but their use in most patients is controversial. Most of the studies using glucocorticoids in the treatment of bronchiolitis denied a positive therapeutic effect $8,9,10$. The use of $ß 2$ agonists occasionally resulted in a short-term improvement in patients with bronchiolitis, especially when using epinephrine, 11-14 while others failed to show a significant effect ${ }^{8,15}$. Kabir et al in a study showed that antibiotics are used in almost all cases $(99 \%)$ of bronchiolitis ${ }^{7}$, but the fact is that the antibiotics are of no benefit in the treatment of the condition $^{16}$.

Several studies suggested the use of nebulized 3\% saline solution for infants with bronchiolitis, due to its ability to lower the viscosity of secretions, reduce airway oedema, and improve mucociliary function. Evidence suggests that hypertonic saline solution favorably alters mucociliary clearance in both normal and diseased lungs ${ }^{17-19}$.

To date, there have been 4 trials investigating the use of nebulized $3 \%$ hypertonic saline solution in infants with viral bronchiolitis. In 2 of the studies, the improvement in the clinical severity scores was significant in the group treated with hypertonic saline ${ }^{20,21}$. In other two studies, the hypertonic saline group had a clinically significant reduction in length of hospital stay 22,23 .

A recent Cochrane Database Systemic Review 4 nonemergency based trials $(n=254)$ examined the role of hypertonic saline in acute bronchiolitis. The authors concluded that nebulized 3\% hypertonic saline may significantly reduce the length of hospital stay and improve the clinical severity score in infants with acute viral bronchiolitis ${ }^{24}$. The only significant adverse effect of nebulized hypertonic saline solution is the risk of bronchospasm as was only established in the asthma ${ }^{25}$. There is a fairly clear dose-response relationship for hypertonic saline solution and bronchospasm in individuals with asthma ${ }^{26}$. Required range to induce bronchospasm is from $4.5-7 \%$ saline ${ }^{27}$. Vast majority of patients with bronchiolitis do not have asthma and the pathophysiologic features of typical bronchiolitis do not involve bronchial smooth muscle hyper responsiveness. So concern regarding bronchospasm resulting from the use of $3 \%$ saline solution among patients with bronchiolitis remains theoretical. No evidence has established that $3 \%$ saline solution induces bronchospasm in infants with bronchiolitis ${ }^{23}$.

The common practice is to treat hospitalized babies with acute bronchiolitis with inhalation of sulbutamol diluted in normal saline solution. The present study hypothesized that simply inhalation of hypertonic saline solution without sulbutamol in the form of inhalation by the babies with bronchiolitis may improve their clinical severity scores thereby shortening the length hospitalization.

\section{Materials and methods}

The study was a randomized controlled trial conducted in the department of Pediatric, Dhaka Medical College Hospital (DMCH) from January 2013 to December 2013. Children aged between one month to two years presenting with preceding or existing runny nose, cough, breathing difficulty, chest in drawing and rhonch on auscultation admitted during the study period andfulfilled the predefined enrollment criteria was enrolled consecutively as study population. This study included 90 patients with acute bronchiolitis. The two groups were randomly assigned to $3 \%$ hypertonic saline nebulization $(n=45)$ and $0.9 \%$ normal saline nebulization $(n=45)$. Randomization was done by lottery method, i.e. the parents/ caregiver was given a chance to pick up sealed encoded envelope from a box of eight envelope; Of them 4 containing the name of $3 \%$ hypertonic saline and other 4 containing the name of $0.9 \%$ normal saline. If the envelop contains $3 \%$ nebulized hypertonic saline the child was assigned to Group-I, and if the envelop contains $0.9 \%$ nebulized normal saline was assigned to Group-II. In this way the required numbers of children were randomly distributed between Group-I and Group-II to receive treatment with $3 \%$ nebulized hypertonic saline and $0.9 \%$ nebulized normal saline respectively. Relevant history and physical examination findings were recorded in a pre-tested, semi-structured questionnaire. Variables like clinical severity score assessed by using respiratory distress assessment instrument described by Wang et $\mathrm{al}^{28}$, oxygen saturation in room air were measured and recorded 
Respiratory distress assessment instrument 28

\begin{tabular}{|c|c|c|c|c|c|}
\hline Variables & 0 & 1 & 2 & 3 & Total \\
\hline $\begin{array}{l}\text { Respiratory } \\
\text { rate }\end{array}$ & $\begin{array}{l}<30 \\
\text { breaths/min }\end{array}$ & $\begin{array}{l}31 \text { to } 45 \\
\text { Breaths/min }\end{array}$ & $\begin{array}{l}46 \text { to } 60 \\
\text { Breaths/min }\end{array}$ & $\begin{array}{l}>60 \\
\text { breaths/min }\end{array}$ & 3 \\
\hline Wheezing & none & $\begin{array}{l}\text { Terminal } \\
\text { expiratory } \\
\text { or only with } \\
\text { stethoscope }\end{array}$ & $\begin{array}{l}\text { Entire expiration or } \\
\text { Audible on Expiration } \\
\text { without stethoscope }\end{array}$ & $\begin{array}{l}\text { Inspiration and } \\
\text { expiration without } \\
\text { stethoscope }\end{array}$ & 3 \\
\hline Retraction & none & $\begin{array}{l}\text { Intercostals } \\
\text { only }\end{array}$ & Tracheosternal & $\begin{array}{l}\text { Severe with nasal } \\
\text { flaring. }\end{array}$ & 3 \\
\hline $\begin{array}{l}\text { General } \\
\text { condition }\end{array}$ & normal & & & $\begin{array}{l}\text { Irritable, lethargic, or } \\
\text { poor feeding }\end{array}$ & 3 \\
\hline
\end{tabular}

on admission as baseline characteristics. Oxygen saturation was measured by using noninvasive pulse oxymeter. A child with oxygen saturation value $<90 \%$ was designated as having significant hypoxia. After taking written informed consent drug was given according to dose schedule. Group-I received nebulization with $4 \mathrm{ml}$ of $3 \%$ hypertonic saline and group-II received nebulization with $4 \mathrm{ml}$ of $0.9 \%$ normal saline three times every day at intervals of 8 hours until they were improved enough for discharged 24 . There was no detectable difference in color, smell, or other physical properties existed between $0.9 \%$ saline solution and $3 \%$ saline solution. Each of the two groups received the same supportive measures like propped up positioning, suction when needed, fluid, feeding, oxygen therapy (when oxygen saturation $<90 \%$ ), paracetamol for fever, and counseling. All inhaled treatments were delivered to infants from standard air-compressed nebulizer. Following randomization and intervention, cases were monitored by respiratory dist ress assessment instrument (RDAl) score at 12 hourly intervals till the patient was ready for discharge. Oxygen saturation in room air and the time required from the initiation of the oxygen support to the withdrawal of oxygen therapy was recorded. Oxygen therapy was stopped when the patients breathed in the room air and maintaining $\mathrm{SPO}_{2}>95 \% 29$. Length of hospital stay from admission to time taken to discharged was measured. The decision to discharge the patients was made in the morning rounds by the attending physician, based on clinical grounds alone.Prior permission was taken for this study from the Ethical Review Committee (ERC) of Dhaka Medical College \& Hospital, Dhaka, Bangladesh. The outcome variables were (1) clinical severity score (2) length of hospital stay (3) oxygen saturation in room air (4) duration of oxygen supplementation (5) Side effects of drugs.
Collected data were processed and analyzed using computer software SPSS (Statistical Package for Social Sciences), version 19. The test statistics used to analyze the data presented on categorical scale were Chi-square or Fisher's Exact probability, while the data presented on continuous scale were analyzed using paired t-Test (for comparison data with group) and Unpaired t-Test (for comparison of data between groups). Level of significance was set $5 \%$ and $p$-value $<0.05$ (at $95 \% \mathrm{Cl}$ ) was considered significant.

\section{Results}

Ninety infant with bronchiolitis fulfill inclusion criteria included in the study between January 2013 and December 2013. About 29 (64.4\%) of the children in Group-I(HS) were < 6 months old as opposed to 26 ( $57.7 \%$ ) in Group-II(NS). Very few children were above the age 12 months. The mean age of the children were $5.2 \pm 3.2$ and $5.5 \pm 3.0$ months respectively with a male predominance in the both groups. There was no significant difference between the groups in term of age and sex $(p>0.05)($ Table -1$)$.

Table I

Demographic characteristics between groups

\begin{tabular}{lccc}
\hline Age in months & \multicolumn{2}{c}{ Group } & \\
& $\begin{array}{c}\text { Group-I(HS) } \\
(\mathrm{n}=45)\end{array}$ & $\begin{array}{c}\text { Group-II(NS) } \\
(\mathrm{n}=45)\end{array}$ & $\begin{array}{c}\mathrm{p}- \\
\text { value }\end{array}$ \\
\hline$<6$ & $29(64.4)$ & $26(57.7)$ & \\
$6-12$ & $14(31.1)$ & $15(33.3)$ & \\
$>12$ & $2(4.4)$ & $4(8.8)$ & \\
Mean \pm SD\# & $5.2 \pm 3.2$ & $5.5 \pm 3.0$ & 0.82 \\
Sex * & & & \\
Male & $25(55.5)$ & $26(57.7)$ & 0.50 \\
Female & $20(44.4)$ & $19(42.2)$ & \\
\hline
\end{tabular}


All the cases in both the groups presented with runny nose, cough, breathing difficulty, chest in drawing and rhonchi but feeding difficulty was presenting feature in $25(55.5 \%)$ cases in group- 1 and $26(57.7 \%)$ cases in group -II. Wheezing was presenting feature in $42(93.33 \%$ ) cases in group- 1 and $43(95.55 \%)$ cases in group-II. Only 6(6.66\%) cases in group- I and $8(17.77 \%)$ cases in group -II presented with nasal flaring. In group-I $13(28.8 \%)$ cases and in group -II $12(26.66 \%)$ cases presented with fever. (Table-II).

Table-II

Clinical presentation of the cases on admission

\begin{tabular}{lcc} 
Clinical presentation & \multicolumn{2}{c}{ Group } \\
& Group -I(HS) & Group- II(NS) \\
\hline Runny nose & $45(100)$ & $45(100)$ \\
Cough & $45(100)$ & $45(100)$ \\
Breathing difficulty & $45(100)$ & $45(100)$ \\
Feeding difficulty & $25(55.5)$ & $26(57.7)$ \\
Wheeze & $42(93.33)$ & $43(95.55)$ \\
Chest in-drawing & $45(100)$ & $45(100)$ \\
Nasal flaring & $06(6.66)$ & $08(17.77)$ \\
Tachypnoea & $40(88.88)$ & $39(86.66)$ \\
Tachycardia & $41(91.11)$ & $39(86.66)$ \\
Rhonchi & $45(100)$ & $45(100)$ \\
Fever & $13(28.88)$ & $94.9 \pm 1.7$ \\
Oxygen saturation & $12(26.66)$ & $94.6 \pm 2.6$ \\
(mean \pm SD) & & \\
\hline
\end{tabular}

Baseline (on admission) clinical characteristics of the two study groups like respiratory rate score, wheezing score, retraction score, general condition score, clinical severity score were almost similar in both the groups ( $p>0.05$ in each case)(Table-III).

Table III

Comparison of baseline respiratory distress assessment instrument (RDAl) score

\begin{tabular}{|c|c|c|c|}
\hline \multirow[t]{2}{*}{ Baseline } & \multicolumn{2}{|c|}{ Group } & $p-$ \\
\hline & $\begin{array}{c}\text { Group-I } \\
(\mathrm{HS}) \\
(\mathrm{n}=45)\end{array}$ & $\begin{array}{c}\text { Group-II } \\
\text { (NS) } \\
(n=45)\end{array}$ & value \\
\hline Respiratory rate score & $2.4 \pm 0.5$ & $2.6 \pm 0.4$ & 0.142 \\
\hline Wheezing score & $2.1 \pm 0.5$ & $2.0 \pm 0.3$ & 0.193 \\
\hline Retraction score & $2.0 \pm 0.5$ & $2.0 \pm 0.6$ & 0.859 \\
\hline General condition score & $2.3 \pm 1.3$ & $2.7 \pm 0.9$ & 0.083 \\
\hline Clinical severity score & $9.0 \pm 1.0$ & $9.3 \pm 1.8$ & 0.943 \\
\hline
\end{tabular}

Mean clinical severity score at base line, at 12 hours, at 24 hours, at 36 hours, at 48 hours, at 60 hours, and at 72 hours in Group-I(HS) were 9.0, 8.2, 5.3, 4.3, 2.6, 2.9, 1.7 while in Group-II(NS) score were $9.3,9.0,7.8,6.1,6.1,4.3,4.5,3.5$ respectively. Clinical severity score of both the treatment groups were redu by three days but reduction was more significant in children who received $3 \%$ nebulised hypertonic saline (Figure- 1)

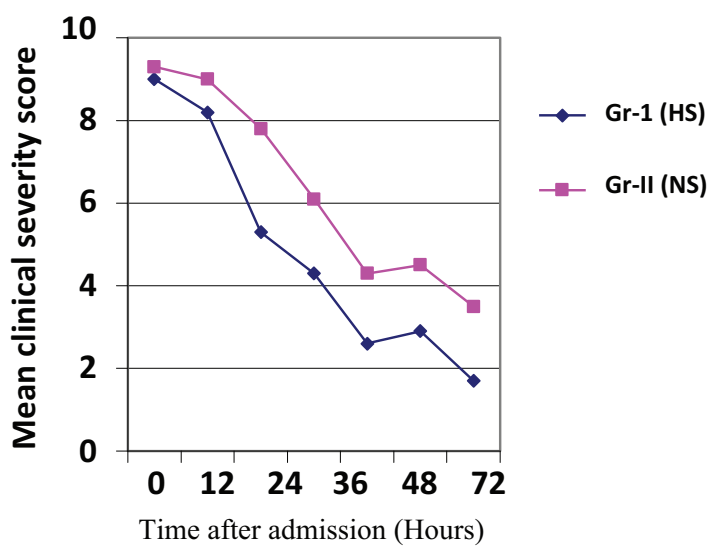

Fig.-1: Comparison of mean clinical severity score of two groups at 12 hourly intervals.

In Group-I (HS) 4 and in Group-II(NS) 5 patients required oxygen supplementation. The patients of Group-I on an average required 15 hours of oxygen therapy, while the patients of Group-II required 26.4 hours of oxygen therapy. Duration of oxygen therapy significantly reduced in Group- I compared to GroupII. (Table- IV)

Table IV

Comparison of duration of oxygen therapy between groups

\begin{tabular}{|c|c|c|c|}
\hline \multirow[b]{2}{*}{$\begin{array}{l}\text { Duration of oxygen } \\
\text { therapy }\end{array}$} & \multicolumn{2}{|c|}{ Group } & \multirow[b]{2}{*}{$\begin{array}{c}\mathrm{p}- \\
\text { value }\end{array}$} \\
\hline & $\begin{array}{c}\text { Group- I } \\
\qquad \begin{array}{c}(\mathrm{HS}) \\
(\mathrm{n}=4)\end{array}\end{array}$ & $\begin{array}{c}\text { Group -II } \\
\text { (NS) } \\
(n=5)\end{array}$ & \\
\hline Mean \pm SD & $15.0 \pm 6.0$ & $26.4 \pm 5.4$ & 0.02 \\
\hline
\end{tabular}

Forty two (93.3\%) of the children in Group-I were recovered by 72 hours and discharged from the hospital whereas $26(57.8 \%)$ of the children in GroupII were recovered and discharged during the same period $(p<0.05)($ Table- $V)$. 
Table- $\mathbf{V}$

Comparison of recovery and discharge from hospital between groups

\begin{tabular}{|c|c|c|c|}
\hline \multirow{2}{*}{$\begin{array}{l}\text { Recovery and } \\
\text { discharge }\end{array}$} & \multicolumn{2}{|c|}{ Group } & \multirow{2}{*}{$\begin{array}{c}p- \\
\text { value }\end{array}$} \\
\hline & $\begin{array}{c}\text { Group-I } \\
(\mathrm{n}=45)\end{array}$ & $\begin{array}{c}\text { Groupll } \\
(n=45)\end{array}$ & \\
\hline Rapid (within 72 hours) & 42(93.3) & $26(57.8)$ & 0.001 \\
\hline Gradual (after 72 hours) & $3(6.7)$ & 19(42.2) & \\
\hline
\end{tabular}

Length of hospital stay was significantly less in GroupI in comparison to group -II $(p<0.05)$. (Table VI). $3 \%$ hypertonic saline nebulisation significantly reduced clinical severity, length of hospital stay and duration of oxygen therapy in case of acute bronchiolitis in comparison to $0.9 \%$ normal saline. Both the modalities of treatment were found to have no adverse effect.

Table VI

Comparison of Length of hospital stays between groups

\begin{tabular}{lllc}
\hline & \multicolumn{2}{c}{ Group } & $p-$ \\
\cline { 2 - 3 } $\begin{array}{l}\text { Length of hospital } \\
\text { stay(hrs) }\end{array}$ & $\begin{array}{c}\text { Group- I } \\
(n=45)\end{array}$ & $\begin{array}{c}\text { Group- II } \\
(n=45)\end{array}$ & value \\
\hline
\end{tabular}

Mean clinical

severity score

Mean \pm SD $\quad 58.1 \pm 22.0 \quad 74.7 \pm 27.2 \quad 0.002$

\section{Discussion}

Bronchiolitis is a common problem in children less than two years of age and is the most common cause of hospitalization for respiratory infection in early child hood3-5. The present study was carried out to see whether $3 \%$ nebulised hypertonic saline reduce clinical severity and length of hospital stay in children with bronchiolitis than does $0.9 \%$ nebulised normal saline. The two study groups in the present study were almost similar with respect to their demographic characteristics like age and sex, baseline clinical characteristics, respiratory distress score like respiratory rate score, wheezing score, retraction score, general condition score, clinical severity score, and oxygen saturation in room air.

The study demonstrated that respiratory rate score, wheezing score, retraction score, general condition score and clinical severity score of both the treatment groups were reduced and oxygen saturation in room air improved within three days but the reduction was much earlier in children who received $3 \%$ nebulised hypertonic saline than those who received $0.9 \%$ nebulised normal saline. The mean duration of oxygen supplementation was 9 hours shorter in the former group than that in the latter group. Majority $(93.3 \%)$ of the $3 \%$ hypertonic saline group children recovered within 72 hours, where as $57.8 \%$ of the children of $0.9 \%$ saline group recovered from the disease during the same period. None of the patients in the present study encountered any side-effects. As all the pertinent baseline clinical characteristics of the two groups of children were similar, the differences in outcome between the groups (better outcome in $3 \%$ nebulised hypertonic saline) can be attributed to intervention.

In the present study $3 \%$ hypertonic saline significantly reduced length of hospital stay. Most patients in hypertonic saline group discharged within 3 days of treatment. Similar observation was seen in another study, mean length of hospital stay was shorter in hypertonic saline group30. Supplementation of oxygen should be based on haemoglobin saturation. If haemoglobin saturation falls persistently below $90 \%$ in bronchiolitis patients, oxygen should be supplemented and may bediscontinued if haemoglobin saturation is at or above $95 \%$ and the infant is feeding well and has minimal respiratory distress29. In the present study the mean duration of oxygen supplementation was significantly shorter in the former group than that in the latter group. Almost similar observation was seen by Martin et al 31.

Consistent with the findings of the present study several investigators have reported the use of hypertonic saline solution for infants in bronchiolitis with substantial benefits of therapy reported by many of them 21-22. The investigators showed that nebulized hypertonic saline (HS) decreases the length of stay in the hospital (LOS) as compared with normal saline (NS) among infants hospitalized with the disease. Many of them used bronchiolitis severity score to evaluate patients over time and they found that inhaled $3 \%$ hypertonic saline with epinephrine administered by nebulization every 6-8 hours improved the bronchiolitis severity score and reduced the length of hospital stay in hospitalized patients when compared with $0.9 \%$ saline with epinephrine 
20, 22-24. None of the studies reported any sideeffects. These findings go in favour the findings of the present study as in the present study the mean length of hospital stay was much shorter (on an average 17 hours shorter) in the hypertonic saline group than that in the isotonic saline group.

A systematic review of four RCTs involving 254 infants with acute viral bronchiolitis (189 inpatients and 65 outpatients) concluded that nebulised $3 \%$ saline may significantly reduce the length of hospital stay and improve the clinical severity score24. However, an orthodox finding was reported by another small RCT which investigated the use of hypertonic saline in the emergency department setting, and the authors suggested that immediate clinical benefits may not be seen with nebulised hypertonic saline32.

Airway oedema and mucus plugging are the predominant pathological features in acute viral bronchiolitis. Hypertonic saline decreases airway oedema, improves mucus rheologic properties and mucociliary clearance, and thus decreases airway obstruction33. It is thought that hypertonic saline facilitates removal of inspissated mucus through osmotic hydration, disruption of mucus strand crosslinking and reduction of mucosal oedema 34, 35.

In summary in this study both treatment groups demonstrated clear evidence of clinical improvement and oxygen saturation but $3 \%$ hypertonic saline group in comparison with $0.9 \%$ normal saline group showed more efficacy in relieving symptom, improving oxygenation and reducing length of hospital stay in infant with acute bronchiolitis. It seems that the use of nebulized

$3 \%$ hypertonic saline in children admitted with moderate to severe viral bronchiolitis is a safe andeffective therapy. This modality being cheap intervention has enormous potential for cost saving both in developing and developed countries, more so, for it reduces the length of hospital stay as evidenced by the findings of the present study and as suggested by a recent Cochrane review 24 . Early, prehospital intervention for bronchiolitis with this safe, effective, and inexpensive agent might save lives, reduce complications and hospitalizations, and can be use where hospital care is not available.

Finally, it can be stated that in 1963, Reynolds and Cook stated that "oxygen is vitally important in bronchiolitis and there is little convincing evidence that any other therapy is consistently or even occasionally useful" 36. Now, fifty years later, supportive care including administration of oxygen and fluids still is the cornerstone of treatment of acute viral bronchiolitis. To this supportive care,

\section{Conclusion}

The study concluded that $3 \%$ hypertonic saline nebulisation significantly reduced clinical severity, length of hospital stay and duration of oxygen therapy in case of acute bronchiolitis in comparison to $0.9 \%$ normal saline. Both the modalities of treatment were found to have no adverse effect.

\section{Recommendation}

A multicentre study with large sample size should be carried out to validate the use of $3 \%$ hypertonic saline nebulisation in reducing clinical severity and length of hospital stay in bronchiolitis.

\section{References}

1. Canny DJ. Acute Bronchiolitis- Recent Advances in Treatment. Indian J Pediatr 1996; 63:45-51.

2. Milder E, Arnold JC. Human Metapnumovirus and Human Bocavirus in Children. Pediatric research 2009; 65(5):78-83.

3. Gleazen WP, Denny FW. Epidemiology of acute lower respiratory disease in children. $\mathrm{N}$ Engl J Med 1973;288:498-505.

4. Ray CG, Minnich LL, Holberg CJ, Shehad ZM, Wright AL, Barton LL, et al. Respiratory syncytial virus-associated lower respiratory illnesses: possible influence of other agents. Pediatr Infect Dis 1993; 12:15-9.

5. Smyth RL, Openshaw PJM. Bronchiolitis. Lancet 2006; 368:312-22.

6. Hall CB. Respiratory syncytial virus and parainfluenza virus. N Engl J Med 2001; 344:1917-28.

7. Kabir ARM, Haq N, Amir R, Hossain A, Khatoon $S$, Shahin A et al. Evaluation of hospitalized infant and young children with bronchiolitis- a multicenter study. Maymensingh Med J 2003 Jul; 12(2):128-133.

8. Darville T, Yamauchi T. Respiratory syncytial virus. Pediatr Rev 1998; 19:55-61. 
9. Van Woensel JB, Wolfs TF, van Aalderen WM, et al. Randomized double blind placebo controlled trial of prednisolonein children admitted to hospital with respiratory syncytial virus bronchiolitis. Thorax 1997; 52:634-637.

10. Cade A, Brownlee KG, Conway SP, et al. Randomised placebo controlled trial of nebulised corticosteroids in acute respiratory syncytial viral bronchiolitis. Arch Dis Child 2000; 82:126-130.

11. Menon K, Sutcliffe T, Klassen TP. A randomized trial comparing the efficacy of epinephrine with salbutamol in the treatment of acute bronchiolitis. J Pediatr 1995; 126:1004- 1007.

12. Dobson JV, Stephens-Groff SM, McMahon SR, et al. The use of albutarol in hospitalized infants with bronchiolitis. Pediatrics 1998; 101:361368.

13. Barr FE, Patel NR, Newth, CJL. The pharmacologic mechanism by which inhaled epinephrine reduces airway obstruction in respiratory syncytial virus associated bronchiolitis. J Pediatr 2000; 136:699-700.

14. Bertrand $\mathrm{P}$, Aranibar H, Castro E, et al. Efficacy of nebulized epinephrine vs salbutamol in hospitalized infants with bronchiolitis. Pediatr Pulmonol 2001; 31:284-288.

15. Flores G, Horwitz RI. Efficacy of ß2-agonists in bronchiolitis: a reappraisal and meta-analysis. Pediatrics 1997; 100:233-239

16. Kabir AR, Mollah AH, Anwar KS, Rahman AK, Amin $R$ and Rahman ME. Management of Bronchiolitis without antibiotics: a multicentre randomized control trial in Bangladesh. Acta Paediatrica 2009;98(10):1593-1599.

17. Wark P, McDonald V, Jones A. Nebulised hypertonic saline for cystic fibrosis. Cochrane Database Syst Rev 2005;(3):CD001506.

18. Tarran R, Donaldson S, Boucher RS. Rationale for hypertonic saline therapy for cystic fibrosis lung disease. Semin Respir Crit Care Med 2007;28(3):295-302.

19. Daviskas E, Anderson SD. Hyperosmolar agents and mucociliary clearance in the diseased airway. J Aerosol Med 2006;19(1): 100 -109 .
20. Sarrell EM, Tal G, Witzling M. et al. Nebulized $3 \%$ hypertonic saline solution treatment in ambulatory children with viral bronchiolitis decreases symptoms. Chest 2002;122: 21520.21. Mandelberg A, Tal G, Witzling M. et al. Nebulized $3 \%$ hypertonic saline solution treatment in hospitalized infants with viral bronchiolitis. Chest 2003;123:481-7

22. Tal G, Cesar K, Oron A, Houri S, Ballin A, Mandelberg A. Hypertonic saline/epinephrine treatment in hospitalized infants with viral bronchiolitis reduces hospitalization stay: 2 year experience. Isr Med Assoc J 2006; 8(3)169173.

23. Kuzik BA, Al-Qadhi SA, Kent S. et al. Nebulized hypertonic saline in the treatment of viral bronchiolitis in infants. J Pediatr 2007; 151: 266270.

24. Zhang L, Mendoza-Sassi RA, Wainwright C, Klassen TP. Nebulized hypertonic saline solution for acute bronchiolitis in infants. Cochrane Database Syst Rev 2008; 8: CD006458.

25. Mai X-M, Nilsson L, Kjellman N-IM, Bjorksten $B$. Hypertonic saline challenge tests in the diagnosis of bronchial hyper responsiveness and asthma in children. Pediatr Allergy Immunol. 2002;13(5):361-367.

26. Smith $\mathrm{CM}$, Anderson SD. Inhalational challenges using hypertonic saline in asthmatic subjects: a comparison with responses to hyperpnoea, methacholine and water. Eur Respir J. 1990;3(2):144-151.

27. Büchele $G$, Rzehak P, Weinmayr $G$, et al. Assessing bronchial responsiveness to hypertonic saline using the stepwise protocol of phase two of the International Study of Asthma and Allergies in Childhood (ISAAC II). Pediatr Pulmonol. 2007;42(2):131-140

28. Wang EEL, Milner RA, Navas L, Maj H. Observer agreement for respiratory signs and oximetry in infants hospitalized with lower respiratory infections. Am Rev Respir Dis 1992; 145:106-9.

29. Luo Z, Liu E, Luo J, Li S, Zeng F, Yang X, et al . Nebulized hypertonic saline/salbutamol solution treatment in hospitalized children with mild to moderate bronchiolitis. Pediatr Int. 2010; 52: 199- 202. 
30. Khalid AA, Sakran M, Bruce L, Davidson, Sayyed $\mathrm{RE}$, Mahjoub $\mathrm{H}$, et al. Nebulized $5 \%$ or $3 \%$ hypertonic or $0.9 \%$ saline for treating acute bronchiolitis in infant. J Padiatr. 2010; 157: 630-4.

31. Martin MR, Yep CG, Sanchez BM, Villalolobos PE, Flores PP. Rev Pediatr Aten Primaria. 2013;15: 109-15.

32. Grewal S, Ali S, McConnell DW, Vandermeer B, Klassen TP. A randomized trial of nebulized 3\% hypertonic saline with epinephrine in the treatment of acute bronchiolitis in the emergency department. Arch Pediatr Adolesc Med 2009; 163:1007-12.
33. Mandelberg A, Amirav I. Hypertonic saline or high volume normal saline for viral bronchiolitis: mechanisms and rationale. Pediatr Pulmonol 2010; 45: 36-40.

34. Robinson M, Daviskas E, Eberl S, et al. The effect of inhaled mannitol on bronchial mucus clearance in cystic fibrosis patients: a pilot study. Eur Respir J 1999; 14: 678-85.

35. Tomooka LT, Murphy C, Davidson TM. Clinical study and literature review of nasal irrigation. Laryngoscope.2000; 110: 1189-93.

36. Reynolds EOR, Cook CD. The treatment of bronchiolitis. J Pediatr. 1963; 63: 1205-7. 